\author{
М. Д. ДЯЧУК
}

\title{
ПОШИРЕНІСТЬ УРОЛОГІЧНОЇ ПАТОЛОГІЇ ТА ПРОБЛЕМИ ОРГАНІЗАЦІЇ НАДАННЯ УРОЛОГІЧНОЇ ДОПОМОГИ НАСЕЛЕННЮ (ОГЛЯД НАУКОВОЇ ЛІТЕРАТУРИ)
}

Державна наукова установа «Науково-практичний центр профрілактичної та клінічної медицини» ДУС, м. Київ, Україна

Мета: виявлення сучасного стану розробки проблеми організації медичної допомоги пацієнтам урологічного профрілю та перспективи подальших досліджень.

Матеріали і методи. При виконанні дослідження використано бібліографічний метод та метод контент-аналізу.

Результати. Незважаючи на тягар медико-соціальних проблем, пов'язаних із хворобами сечостатевої системи, дослідження з цієї тематики є вкрай нечисленні. Вони присвячені вивченню масштабів поширення патології, провідних чинників впливу, удосконаленню технологій лікування, вирішенню питань боротьби з окремими хворобами сечостатевої системи, насамперед із сечокам'яною хворобою, інфекціями та хронічними хворобами нирок, та організації медичної допомоги окремим категоріям населення, переважно в регіональному контексті.

Залишаються невирішеними питання медико-організаційного характеру. Це вимагає комплексного підходу 3 урахуванням широкого спектра патології, багатьох чинників впливу, сучасних стратегій розвитку урологічної служби, інтегративних тенденцій, профрілактичних концепцій, пацієнторієнтованого підходу тощо.

Висновки. Аналіз наукової літератури виявив недостатню розробку проблеми скорочення урологічної патології, ії негативних наслідків, засвідчив необхідність наукового обґрунтування удосконалення системи надання урологічної допомоги населенню за умов ресрормування охорони здоров'я.

КЛЮЧОВІ СЛОВА: хвороби сечостатевої системи; захворюваність; поширеність; організація урологічної допомоги; чинники; якість; функціонально-структурна модель.

Глобальними цілями стійкого розвитку та стратегічними пріоритетами європейської політики «Здоров'я - 2020» є досягнення якомога вищого рівня здоров'я, скорочення захворюваності та смертності населення, подовження активного довголіття. Досягнення стратегічних орієнтирів нової європейської політики в охороні здоров'я лежить у площині забезпечення соціальної справедливості й добробуту, задоволення потреб населення в охороні здоров'я, для всіх у будь-якому віці відповідно до затверджених Цілей у сорері сталого розвитку [20, 39].

3 огляду на вказане у 2017 р. в Європейському регіоні ВООЗ прийнято «Дорожню карту щодо реалізації Порядку денного в галузі сталого розвитку на період до 2030 р. з опорою на політику «Здоров'я - 2020» - основу європейської політики на підтримку здоров'я і благополуччя», яка надає міжсекторальний інструментарій державам-членам у реалізації стратегічних орієнтирів. Іншим документом «Здійснення концептуального бачення політики «Здоров'я - 2020»: стратегічне керівництво в інтересах здоров'я» представлено керівництво в просуванні та вдосконаленні розумного стратегічного управління в інтересах здоров'я для досягнення реальних результатів у поліпшенні здоров'я населення [22].
Реалізація цілей щодо досягнення високих стандартів здоров'я і благополуччя передбачає вплив на провідні детермінанти здоров'я, активне утвердження здорового способу життя, підвищення якості та доступності послуг охорони здоров'я на всіх рівнях надання медичної допомоги і загального охоплення ними населення [4, 33].

Моніторинг прогресу в досягненні стратегічних пріоритетів вимагає аналізу особливостей та тенденцій показників здоров'я населення, пов'язаних із ними детермінант, чинників ризику тощо, оцінки ресурсного забезпечення, діяльності фрахівців і закладів різних профрілів медичної допомоги щодо задоволення існуючих потреб громадян.

Враховуючи значну поширеність патології сечостатевої системи та тенденції до її збільшення за умов старіння населення, негативного впливу багатьох чинників, а також значущість урологічної допомоги у попередженні ускладнень захворювань, інвалідизації і смертності, у зменшенні страждань людей, ми розглядали стратегічні пріоритети саме під кутом урологічного здоров'я.

Мета дослідження: виявлення сучасного рівня розробки проблем скорочення урологічної патології та організації медичної допомоги пацієнтам урологічного профілю, встановлення невирішених проблем та перспективних напрямів подальших досліджень. 
Матеріали і методи. При виконанні дослідження використано бібліографічний метод та метод контент-аналізу.

Результати дослідження та їх обговорення. Поліпшення популяційного здоров'я та скорочення глобального тягаря хвороб потребує особливої уваги до провідних причин нездоров'я, у тому числі до захворюваності населення на хвороби сечостатевої системи [34].

Аналіз наукових публікацій свідчить про значну поширеність цієї патології серед населення і її негативних наслідків для здоров'я та якості життя людей.

Згідно з даними ВООЗ, хвороби сечостатевої системи уражають людей будь-якого віку, у тому числі молодих людей віком до 40 років. Вони включають аномалії розвитку, травматичні ушкодження та новоутворення сечової та чоловічої статевої сорери, інфрекційно-запальні захворювання, сечокам'яну хворобу, гідронефроз, гостру та хронічну ниркову недостатність тощо. Саме ці хвороби є найчастішою причиною тимчасової та стійкої втрати працездатності значної чисельності населення, роблять серйозний внесок у фрормування рівнів смертності населення та глобального тягаря хвороб $[40,41]$.

На значну поширеність хвороб сечостатевої системи серед населення вказують наукові дослідження, проведені в США, Канаді, Австрії, Німеччині, Великій Британії, Польщі, Туреччині, Китаї, Ірані, Кореї, Японії та інших країнах [35, 36, 38, 42, 46-48, 50].

За даними III Національного огляду США зі здоров'я та харчування, поширеність хронічних захворювань нирок серед дорослого населення США складала 11 \%. При цьому, 3,3 \% мали I стадію зі стійкою альбумінурією і нормальною швидкістю клубочкової фрільтрації, 3,0 \% - II стадію хвороби, 4,3 \% - III стадію, по 0,2 \% - IV і V стадії. У ході дослідження було встановлено, що окрім артеріальної гіпертензії та діабету, вік був ключовим предиктором хронічної хвороби нирок [46].

За даними Канадського дослідження заходів 3 охорони здоров'я, проведеного у 2007-2009 рр. із вивчення поширеності хронічних захворювань нирок, було виявлено, що поширеність захворювань нирок становила 12,5\%. Оцінка поширеності захворювань на III-V стадії засвідчила наявність їх у 3,1 \% населення. Поширеність цукрового діабету, гіпертензії та гіпертригліцеридемії були значно вищими у дорослих із хронічною хворобою нирок, ніж серед населення без вказаної патології [38].

Згідно 3 результатами епідеміологічних досліджень у Німеччині, 17,4 \% пацієнтів закладів охорони здоров'я мали хронічні захворювання нирок. Поширеність I, II, III, IV-V стадій становила 4,6, 4,7, 17,0 та 0,4 \% відповідно. Показники поширеності патології нирок серед населення 3 віком мали негативну тенденцію до зростання і досягли максимальних значень у віці 70-74 роки $(23,9 \%)$ [36].

Аналіз поширеності хронічної хвороби нирок серед населення Англії у 2003 р. та в порівнянні з 2009-2010 рр. виявив тенденцію до її скорочення, незважаючи на зростаючу поширеність ожиріння та діабету як основних причин розвитку патології [50].

Вивчення поширеності хронічних захворювань нирок серед населення Польщі дозволило встановити їх зв'язок з соціально-економічними умовами життя населення літнього віку [48].

Наукові джерела свідчать, що у Китаї поширеність хронічних захворювань нирок варіювала в межах 8-10 \%. Чинниками, що суттєво впливали на величину показників поширеності нефрологічної патології на різних територіях, були вік, стать, гіпертензія, наявність цукрового діабету, історія серцево-судинних захворювань, гіперурикемія, місце проживання та економічний стан родини [35].

За даними різних дослідників, діапазон захворюваності на патологію сечостатевої системи Є досить великим у країнах Східної Європи. Зокрема, захворюваність дорослого населення на хвороби сечостатевої системи за зверненнями в заклади охорони здоров'я коливалася 7093,0-12071,3 випадків на 100 тис. відповідного населення [18]. Захворюваність на сечокам'яну хворобу становила 4,47 на 1000 дорослого населення і варіювала в широких межах 1,28-10,24 на окремих територіях [8].

Виявлено значні територіальні відмінності в поширеності патології сечостатевої системи в межах одного регіону, які досягають серед юнаків - 112 разів, серед чоловічого населення майже 18 разів [12]

У структурі смертності населення економічно розвинених країн хвороби сечостатевої системи займають 7 місце і складають 2,5-3,0 \% усіх причин смертності, що вказує на масштаби поширення патології, її найтяжчих фрорм у популяції та на недосконалість технологій та організаційних форм її лікування.

У науковій літературі наголошується на негативних тенденціях захворюваності населення на хвороби сечостатевої системи. Так, відзначається, що рівень хвороб сечостатевої системи збільшився впродовж 2000-2012 рр. на 51,4 \%, а серед дитячого населення приріст вказаної патології склав 79,1 \% [8].

За даними інших дослідників, лише за 6 років, 2005-2010 рр., захворюваність за зверненнями міського дорослого населення на хвороби сечостатевої системи зросла на 14,2 \% [18].

Встановлено, що швидкими темпами відбувається погіршення урологічного здоров'я чоловічої частини населення. Проте наявна інформація 
$€$ суперечливою та обмеженою за обсягом. У період 2004-2009 рр. виявлено зростання захворюваності та поширеності хвороб сечостатевої системи у юнаків - на 7,6 та 21,3\%, хвороб передміхурової залози у чоловіків - на 91,8 та 85,6 \%, чоловічого безпліддя - на 260,0 та 280,0 \% [12].

Негативні тенденції урологічного здоров'я чоловіків спричиняють погіршення інтегральних показників здоров'я чоловічого населення, що було предметом окремого розгляду на 68 сесії Європейського регіонального комітету ВООЗ у 2018 р. У ході широкого обговорення цього питання було визначено перспективні шляхи подолання негативних тенденцій. У звіті про здоров'я і благополуччя чоловіків аналізують глибинні причини їх ставлення до здоров'я. Прийнята на форумі Стратегія на підтримку здоров'я і благополуччя чоловіків у Європейському регіоні ВООЗ передбачає застосування гендерних підходів, які допоможуть чоловікам отримувати доступ до необхідних послуг. Завдання стратегії передбачають зниження передчасної смертності чоловіків від неінфекційних захворювань і ненавмисних та навмисних травм; скорочення нерівності щодо соматичного і психічного здоров'я і благополуччя між чоловіками в будь-якому віці в межах регіону і окремих країн; поліпшення показників гендерної рівноправності, підтримуючи роль чоловіків як батьків, залучаючи їх до самодопомоги, здійснення неоплачуваного догляду, запобігання насильству та охорони сексуального і репродуктивного здоров'я [28].

На актуальність боротьби з урологічною патологією в Україні вказує низка наукових публікацій, що свідчать про зростання поширеності хвороб сечостатевої системи, у тому числі інфрекцій нирок та сечовивідних шляхів, пієлонефриту, сечокам'яної хвороби, хронічної хвороби нирок та раку, аденоми простати, чоловічого безпліддя тощо [21, 24, 31]. Зокрема, дослідження поширеності сечокам'яної хвороби серед населення Прикарпатського регіону виявило стійку тенденцію до її зростання [31], як і серед контингенту військовослужбовців [21].

У наукових публікаціях аналізують тренди інвалідності населення внаслідок хвороб сечостатевої системи, які стосуються різних вікових груп та окремих причин інвалідності через патології цього класу [27].

Особливої уваги заслуговують питання дитячої інвалідності, які характеризують основні причини та тенденції інвалідності. Спостерігають збільшення показника дитячої інвалідності, однією з причин якої $€$ хвороби нирок $[10,29]$. У структурі інвалідизуючих захворювань органів сечовидільної системи дітей уроджені та спадкові нефропатії переважають над набутими. Зокрема, вивчення структури інвалідизуючих захворювань нефрроурологічного профрілю у дитячого населення одного з регіонів України показало, що 50 \% припадає на аномалії органів сечовидільної системи, 17,5 \% - на гломерулярні ураження, $22 \%$ - на гломерулонефрит із гематуричним синдромом та 16 \% - з гломерулонефритом на тлі геморагічного васкуліту [29].

Відмінності в показниках захворюваності населення на хвороби сечостатевої системи на різних територіях, на думку дослідників, пов'язані 3 недосконалістю профілактики, недостатньою укомплектованістю фрахівцями первинної ланки, їх кваліфікацією, якістю діагностики та медико-технічною оснащеністю закладів охорони здоров'я [3, 25].

Автори наукових публікацій стверджують, що складність питань профілактики патології сечостатевої системи полягає у комплексі причин, у тому числі в багатофракторності захворювань [18, $43,48,49]$. Серед сучасних викликів і загроз для здоров'я населення особливої уваги потребують також демографрічні тренди, що супроводжуються старінням і призводять до збільшення частоти асоційованих із віком захворювань, включно урологічні хвороби $[14,44]$.

Логічним висновком проведених досліджень $€$ думка про те, що значна прогресуюча деградація довкілля і посилення екологічного неблагополуччя підвищують ризик розвитку багатьох хвороб сечостатевої системи [12]. Негативну роль у формуванні тягаря урологічних захворювань відіграють несприятливі соціально-економічні детермінанти та низька якість життя [45].

3 огляду на частоту захворювань сечостатевої системи та їх ускладнень зрозумілим $€$ масштаб викликаних ними економічних збитків для суспільства, країн, громад, окремих сімей [37].

Значні рівні захворюваності та поширеності хвороб сечостатевої системи, негативні тенденції до їх збільшення вимагають удосконалення моніторингу та оцінки епідеміологічних процесів, попередження, вчасного та повного виявлення урологічної патології, якісного її лікування. Це висуває актуальні завдання з оптимізації організації надання медичної допомоги населенню 3 урологічною патологією за умов реформування охорони здоров'я.

У наукових роботах підкреслюють, що стратегічний напрям розвитку національних систем охорони здоров'я 3 пріоритетом на профрілактику та первинну медичну допомогу потребує перерозподілу обсягів медичної допомоги пацієнтам із захворюваннями сечостатевої системи між різними ланками її надання 3 акцентом на загальну практику. Водночас, несприятливий перебіг, прогресування багатьох нозологічних форм, що супроводжується значним числом різних ускладнень, вимагає удосконалення спеціалізованого лікування у лікарів урологічного профілю, пошуку 
нових форм організації урологічної допомоги населенню на усіх рівнях $[2,23]$.

Окремі дослідження присвячено удосконаленню клініко-організаційних моделей урологічної допомоги хворим [6], комплексному лікуванню та профрілактиці окремих захворювань сечостатевої сорери, зокрема уретеролітіазу [30], сечокам'яної хвороби [5, 17], засад медико-психологічної допомоги хворим на сечокам'яну хворобу однієї або єдиної нирки тощо [1].

На основі результатів багатофракторного аналізу встановлено, що рівень урологічного здоров'я чоловічої частини населення визначають впливом складного комплексу медико-організаційних, соціально-економічних і демографічних чинників. За результатами проведеного дослідження запропоновано трирівневу організаційну систему надання спеціалізованої допомоги чоловікам i юнакам, яка дозволяє підвищити доступність високотехнологічної медичної допомоги, та мережу експрес-діагностичних урологічних відділень, що забезпечує підвищення виявлення усіх видів андрологічної патології [11].

Науковими дослідженнями доведено, що в організації консультативно-діагностичної допомоги урологічного профрілю велике значення має лабораторно-діагностичне обстеження хворих. Тому було запропоновано організацію консультативно-діагностичної допомоги на базі медичного університету. Перевагою такого підходу автори вважають можливість в необхідних випадках використовувати як весь арсенал діагностичного обладнання консультативно-діагностичного центру для лабораторно-діагностичного обстеження амбулаторних хворих, так і оснащення спеціалізованих клінік закладів вищої освіти. Цю думку підтверджує той фракт, що практично всі пацієнти консультативно-діагностичного центру потребували якогось лабораторного діагностичного обстеження. У ході дослідження було виявлено, що серед пацієнтів урологічного відділення консультативно-діагностичних центрів, яким проводили необхідний комплекс маніпуляцій при певних захворюваннях, у тому числі при хронічному простатиті, хронічному циститі, сечокам'яній хворобі, 80,0-98,0 \% потребували не тільки лабораторного обстеження та УЗД, а й інших досліджень, більшу частину з яких не можна було здійснити в умовах районної поліклініки. Проте ці дослідження можна було провести в умовах спеціалізованої клініки медичного університету. Однією з функцій урологічного відділення консультативно-діагностичного центру є відбір для госпіталізації пацієнтів. Встановлено, що третині хворих, які звернулися в урологічне відділення консультативно-діагностичного центру, було рекомендовано госпіталізацію [13].

Аналіз випадків госпіталізації хворих в урологічне відділення пілотної міської лікарні показав, що середньорічна частка госпіталізованих в урологічне відділення за екстреними показаннями склала 46,4 \%. Проведена експертиза обґрунтованості термінів лікування хворих в урологічному відділенні засвідчила, що у 22,0 \% хворих були необґрунтовано високі терміни лікування. Найбільшу питому вагу завищених термінів госпіталізації виявлено серед хворих, які лікувалися з приводу сечокам'яної хвороби (37,1%), гіперплазії передміхурової залози (18,1 \%), інфекцій сечостатевої системи (14,3\%), захворювань чоловічих статевих органів (11,9\%), пухлин органів сечостатевої системи (4,2 \%) та ін. На думку експертів, терміни госпіталізації в урологічні відділення можуть бути суттєво скорочені як на початковому, так і в активному періодах лікування. Проведений аналіз свідчить про суттєві резерви скорочення термінів лікування урологічних хворих у стаціонарі цілодобового перебування. Їх можливо досягти за рахунок інтенсифікації лікувального процесу в лікарняному закладі та шляхом широкого впровадження стаціонарозамінних технологій [19].

Аналіз даних про обсяги та якість надання медичної допомоги хворим на сечокам'яну хворобу та інфекції сечостатевої системи на поліклінічному і стаціонарному етапах свідчить про суттєві недоліки цієї роботи на поліклінічному рівні. Це підтверджується тим, що понад 95 \% хворих на сечокам'яну хворобу та інфекції сечостатевої системи госпіталізують в стаціонар службою екстреної медичної допомоги, а не планово. Встановлено, що у віковій структурі пацієнтів 3 інфекціями сечостатевої системи переважають хворі віком 41-50 років із питомою вагою 30,2 \% і 51-60 років - 3 часткою 28,6 \%. 3 метою оптимізації управління процесом надання урологічної медичної допомоги хворим із захворюваннями сечостатевої системи запропоновано застосування комплексного підходу до планування заходів на поліклінічному і стаціонарному етапах. Він передбачає аналіз захворюваності населення за зверненнями в заклади охорони здоров'я, врахування впливу екзогенних факторів ризику, оцінку кадрового та технічного забезпечення урологічних відділень, механізм ефективної взаємодії медичних служб різних рівнів тощо [7].

Низку досліджень присвячено вивченню ефективності регіональних урологічних служб. Вони свідчать про скорочення спеціалізованого ліжкового фронду та зниження функції лікаря-уролога з одночасним підвищенням інтенсифрікації використання урологічних стаціонарних ліжок. Автори вказують, що незважаючи на повне скорочення урологічних ліжок у центральних районних лікарнях, близько $50 \%$ пацієнтів із захворюваннями сечостатевої системи госпіталізують в терапевтичні та хірургічні відділення. 3 огляду на 
вказане, доцільним є впровадження алгоритму організаційних технологій з управління маршрутами пацієнтів для отримання спеціалізованих видів медичної допомоги населенню за направленням лікарів центральних районних лікарень, створення міжмуніципальних центрів консультативнодіагностичної та стаціонарної допомоги населенню області в багатопрофрільних лікарнях [26].

Оптимізації регіональної системи надання урологічної допомоги населенню присвячено дослідження 3 удосконалення організації та лікування сечокам'яної хвороби. На основі виявлених недоліків функціонування регіональної системи надання допомоги пацієнтам із сечокам'яною хворобою та 3 урахуванням перспективних підходів було запропоновано інтегративну модель організації медичної допомоги при сечокам'яній хворобі на регіональному рівні 3 концентрацією сучасної хірургічної урологічної допомоги в окремих високотехнологічних закладах охорони здоров'я, забезпеченням ургентної урологічної допомоги на базі відділень екстреної допомоги лікарень інтенсивного лікування, амбулаторної - на базі районних та міських консультативно-діагностичних центрів, вчасним виявленням патології тощо [5].

Значну увагу в науковій літературі приділено удосконаленню організації реабілітаційної медичної допомоги пацієнтам з урологічною патологією [9, 32]. Зокрема, для поліпшення результатів оперативного лікування хворих на сечокам'яну хворобу рекомендовано проведення реабілітаційних заходів у санаторних умовах безпосередньо після виписування зі стаціонару на термін до 2-3 тижнів, розробку індивідуальної програми клінічної та трудової реабілітації в найближчий післяопераційний період залежно від локалізації, розміру каменя і методу оперативного лікування сечокам'яної хвороби, здійснення диспансерного спостереження, поліпшення фрахової підготовки лікарів-урологів у закладах вищої освіти на додипломному та післядипломному рівнях.

Важливим напрямом наукових досліджень стала оцінка якості життя пацієнтів із патологією сечостатевої системи $[15,16]$. Так, за даними соціологічних опитувань, серед пацієнтів із сечокам'яною хворобою середню оцінку якості життя дали 57 \% респондентів, хорошу - тільки $28 \%$ респондентів, а середній бал склав 3,76. Найбільшою частка респондентів, які відзначили поганий стан здоров'я, була серед хворих на захворювання чоловічих статевих органів (16,4\%). Оцінили свій стан як посередній в основному пацієнти $з$ травмами органів сечостатевої системи $(66,7 \%)$, захворюваннями чоловічих статевих органів (66,7 \%), сечокам'яною хворобою (65,7\%), гіперплазією передміхурової залози (58,3%) та інфекціями сечостатевих шляхів (55,8 \%). у ході дослідження було виявлено тенденцію до зниження якості життя за всіма складовими, включно фізичну, психічну, соціальну, духовну і загальне сприйняття власного стану пацієнтами. Якість життя пацієнтів 3 патологією сечостатевої системи свідчить про необхідність поліпшення профрілактичної роботи та підвищення ефективності лікувально-діагностичного процесу [16].

Вирішення питань профрілактики захворювань сечостатевої системи та організації медичної допомоги пацієнтам із цією патологією лежить у площині запровадження моніторингу особливостей та тенденцій їх поширеності, оцінки доступності і якості, визначення ефективності для обґрунтування управлінських заходів. У цьому контексті важливим $€$ врахування підходів та ефективних стратегій, які окреслено низкою програмних і стратегічних документів державного та міжнародного рівня, насамперед Основами європейської політики «Здоров'я - 2020» та Національною стратегією реформування системи охорони здоров'я в Україні на період 2015-2020 pp.

Незважаючи на масштаби поширеності хвороб сечостатевої системи та тягар пов'язаних із ними медико-соціальних проблем, дослідження з удосконалення організації спеціалізованої урологічної допомоги вкрай нечисленні.

Переважна більшість робіт стосується особливостей захворюваності та поширеності хвороб сечостатевої системи в різних країнах світу, в окремих регіонах та групах населення. Частину робіт присвячено технологічним аспектам діагностики та лікування, вирішенню питань боротьби з окремими хворобами сечостатевої системи, насамперед із сечокам'яною хворобою, інфекціями нирок, доброякісною гіперплазією передміхурової залози тощо, та організації медичної допомоги окремим категоріям населення, переважно в регіональному контексті.

Аналізуючи наукову літературу, можна зробити висновок про те, що існує нагальна необхідність в підвищенні доступності та поліпшенні якості медичних послуг для пацієнтів із урологічною патологією, впровадження нових технологій та організаційних моделей їх надання для досягнення загального охоплення населення.

Залишаються невирішеними питання медикоорганізаційного характеру. Це вимагає комплексного підходу з урахуванням широкого спектра патології, багатьох чинників впливу, викликів та загроз для урологічного здоров'я з використанням сучасних стратегій розвитку урологічної служби, інтегративних тенденцій, профрілактичних концепцій, пацієнторієнтованого підходу, державно-приватного партнерства тощо за умов здійснення реформ в охороні здоров'я.

\section{Висновки}

Аналіз праць вітчизняних авторів та іноземних наукових джерел дозволив підтвердити 
масштабність і соціальну значущість проблем урологічного здоров'я, узагальнити міжнародний досвід щодо організації надання урологічної медичної допомоги, зробити висновок про актуальність подальших досліджень, спрямованих на оптимізацію діяльності урологічної служби.

Вивчення наукової літератури з проблеми, що досліджують, виявило негативні тенденції до збільшення поширеності захворювань сечостатевої системи в багатьох регіонах, потребу в удосконаленні моніторингу та оцінки епідеміологічних процесів, профілактики урологічної патології на основі доказової бази, оптимізації організації надання медичної допомоги за умов реформування охорони здоров'я.
Перспективи подальших досліджень. Виявлено в багатьох дослідженнях невисоку доступність урологічної допомоги, недостатній облік захворювань та несвоєчасне їх виявлення, існує потреба в цілеспрямованих дослідженнях зі встановлення вичерпної захворюваності населення на хвороби сечостатевої системи, оцінки якості медичної допомоги з точки зору надавачів, споживачів послуг та управлінців, розробки заходів, спрямованих на підвищення доступності та еорективності профрілактики і лікування широкого спектра урологічної патології, обґрунтування та впровадження сучасних фрункціонально-структурних моделей надання медичної допомоги урологічного профрілю.

\section{Список літератури}

1. Балка Л. О. Обґрунтування загальних засад медико-психологічної допомоги хворим на сечокам'яну хворобу однієї або єдиної нирки / Л. О. Балка // Медична психологія. - 2015. - № 2. - С. 53-56.

2. Возіанов С. О. Ресурси та основні показники діяльності урологічної служби в Україні за 50 років / С. О. Возіанов,

Н. О. Сайдакова, Л. М. Старцева // Урологія. - 2015. - Т. 19, № 2 (73). - С. 9-19.

3. Возіанов С. О. Стан і перспективи розвитку урологічної служби в Україні / С. О. Возіанов, Н. О. Сайдакова, Л. М. Старцева // Урологія. - 2013. - Т. 17, № 3. - С. 89-95.

4. Грузєва Т. Інноваційна сутність та стратегічний і практичний потенціал нової Європейської політики «Здоров'я 2020» / Т. Грузєва // Вісник пробл. біології та медицини. - 2014. - Т. 1 (110). - С. 25-33.

5. Децик О. З. Сучасні підходи до організації надання ургентної і планової медичної допомоги при сечокам'яній хворобі / О. 3. Децик, Д. Б. Соломчак // Здоровье мужчины. - 2017. - № 2 (61). - С. 58-61.

6. Дмитришин С. П. Клініко-організаційна модель урологічної допомоги хворим на сечокам'яну хворобу : авторефр. дис. на здобуття наук. ступеня канд. мед. наук : спец. 14.01.06 «Урологія» / С. П. Дмитришин. - К., 2012. - 20 с.

7. Дулов А. А. Организация медицинской помощи больных с заболеваниями мочеполовой системы / А. А. Дулов, В. А. Борисов, Г. В. Попова // Системный анализ и управление в биомедицинских системах. - 2014. - Т. 13, № 1. C. $150-156$.

8. Дулов А. А. Оценка уровня заболеваемости болезнями мочеполовой системы и экзогенных фракторов риска / А. А. Дулов, В. А. Борисов, О. В. Клепиков // Системный анализ и управление в биомедицинских системах. - 2013. T. 12, № 1. - С. 331-337.

9. Журавлев В. Н. Клиническая и трудовая реабилитация больных при крупных камнях почек после ДУВЛ в условиях санатория «Обуховский» / В. Н. Журавлев, С. Г. Вахлов, А. А. Макарян // Уральский медицинский журнал. - 2009. № 11 (65). - С. 19-22.

10. Инвалидность детей с хроническими соматическими заболеваниями в Украине / Н. М. Коренев, С. Р. Толмачева, Л. Ф. Богмат, А. М. Коломиец // Здоровье ребенка. - 2009. - № 3 (18). - С. 25-31.

11. Коган О.С. Некоторые результаты реорганизации системы урологической помощи мужчинам в Свердловской области / О. С. Коган, Ф. И. Бадаев // Вестн. Уральск. мед. акад. науки. - 2010. - № 4. - С. 69-71.

12. Коган О. С. Состояние урологического здоровья населения в муниципальных образованиях Свердловской области и фракторы его формирующие / О. С. Коган // Проблемы управления здравоохранением. - 2010. - № 6. с. 44-47.

13. Крылов С. Г. Анализ результатов социологического исследования пациентов урологического отделения консультативно-диагностического центра / С. Г. Крылов // Гуманитарные методы исследования в медицине: состояние и перспективы : материалы научн.-практ. конфр. (Саратов, март, 2007 г.). - Саратов : СМУ, 2007. - С. 308-310. 14. Крылов С. Г. Медико-статистическая характеристика больных урологического отделения областной больницы / С. Г. Крылов, К. С. Асатрян // Проблемы городского здравоохранения. - Вып. 11. - СПб., 2006. - С. $149-152$.

15. Кучма І. Л. Порівняльна оцінка якості життя пацієнтів, які отримують ниркову замісну терапію, при використанні стандартних та індивідуальних програм лікування / І. Л. Кучма // Медична інформатика та інженерія. - 2013. - № 3. C. 24-27.

16. Макарян А. А. Качество жизни больных мочекаменной болезнью после проведенного лечения / А. А. Макарян // Материалы 67-й Всероссийской научно-практической конференции молодых ученых и студентов с международным участием. - Екатеринбург, 2012. - С. 603-606.

17. Макарян А. А. Организация клинической реабилитации больных мочекаменной болезнью после проведенного оперативного лечения в санатории «Обуховский» / А. А. Макарян, В. Н. Журавлев, И. В. Борзунов // Фармация и общественное здоровье : материалы Ежегодной конореренции. - Екатеринбург, 2012. - С. 370-372. 
18. Машин А. Г. Заболеваемость и инвалидность в связи с болезнями мочеполовой системы / А. Г. Машин // Актуальные аспекты внедрения инновационных технологий в практику осуществления медико-социальной экспертизы с использованием положений МКФ. - Ростов-на-Дону, 2011. - С. 285-286.

19. Машин А. Г. Ресурсосберегающие технологии в урологии / А. Г. Машин // Теория и практика достижений современной медицины : материалы Межинститутской научной конференции с международным участием, посвященной 100-летию со дня рождения Г. Н. Белецкого, 19 октября 2011 г. - М. : ГБОУ ВПО МГМСУ, 2011. C. $47-48$.

20. Местоздравоохраненияв Повестке дня в области развития напериодпосле 2015 г. [Электронный ресурс]. - Режим доступа : http://www.who.int/topics/millennium_development_goals/post2015/WHOdiscussionpaper_October2012_ru.pd. 21. Мосієнко Г. П. Поширеність сечокам'яної хвороби серед військовослужбовців за даними ультразвукової діагностики / Г. П. Мосієнко // Здоровье мужчины. - 2013. - № 2 (45). - С. 117-119.

22. Осуществление концептуального видения политики Здоровье-2020: стратегическое руководство в интересах здоровья в XXI веке // Копенгаген, ЕРБ ВОЗ, 2014 г. - 99 с.

23. Пасєчніков С. П. Динаміка ефективності та рівня організації спеціалізованої допомоги пацієнтам із сечокам'яною хворобою в Україні / С. П. Пасєчніков, Н. О. Сайдакова, С. П. Дмитришин // Здоровье мужчины. - 2009. - № 1. C. $164-171$.

24. Первинна, загальна захворюваність, смертність від основних хвороб органів сечостатевої системи в аспекті діяльності ДУ «Інститут урології НАМН України» / С. О. Возіанов, Н. О. Сайдакова, В. М. Григоренко [та ін.] // Урологія. - 2015. - Т. 19, № 3 (74). - С. 15-28.

25. Прибытков Г. Н. Современные тенденции в заболеваемости органов мочеполовой системы у населения юга Тюменской области / Г. Н. Прибытков // Медицинская наука и образование Урала. - 2007. - № 3. - С. 57-59.

26. Прибытков Г. Н. Урофрлоуметрический контроль при лечении хронического простатита / Г. Н. Прибытков, В. И. Максимовских, А. А. Мариупольский // Научный вестник Тюменской медицинской академии. - 2001. № 2. - С. 23.

27. Причини інвалідності населення України внаслідок захворювань сечостатевої системи та шляхи їх зменшення / Е. О. Стаховський, Н. О. Сайдакова, Ю. В. Вітрук, С. П. Дмитришин // Урологія. - 2017. - Т. 21 , № 1 (80). - С. $45-52$. 28. Резолюция «Стратегия в поддержку здоровья и благополучия мужчин в Европейском регионе ВОЗ» [Электронный ресурс]. - Режим доступа : http://www.euro.who.int/_data/assets/pdf_file/0003/382251/68rs04r_ MensHealthStrategy_180668.pdf?ua=1.

29. Руда В. І. Рівень інвалідності при захворюваннях органів сечовидільної системи у дітей Хмельницької області / В. І. Руда // Актуальные вопросы педиатрии. - 2015. - № 4 (68). - С. 53-56.

30. Собчинський К. С. Комплексне лікування уретеролітіазу в амбулаторних умовах та просрілактика його ускладнень : авторефр. дис. на здобуття наук. ступеня канд. мед. наук : 14.01 .06 «Урологія» / К. С. Собчинський. - К., $2016 .-23$ с. 31. Соломчак Д. Б. Аналіз організації диспансерного спостереження хворих на сечокам'яну хворобу / Д. Б. Соломчак // Галицький лікарський вісник. - 2015. - Т. 22, № 1. - С. 127-130.

32. Соломчак Д. Б. Аналіз організації санаторно-курортного лікування хворих на сечокам'яну хворобу / Д. Б. Соломчак // Медична гідрологія та реабілітація. - 2015. - Т. 12, № 1-4. - С. 7-14.

33. Сучасні напрями розвитку систем охорони здоров'я країн Європи : наук.-метод. рек. / авт. кол. : В. М. Князевич, М. М. Білинська, Л. І. Жаліло та ін. ; за ред. д-ра мед. наук В. М. Князевича. - К. : НАДУ, 2015. - 40 с.

34. Щорічна доповідь про стан здоров'я населення, санітарно-епідемічну ситуацію та результати діяльності системи охорони здоров'я України. 2016 рік / МОЗ України, ДУ «УІСД МОЗ України». - К., 2017. - 512 с.

35. A population-based survey of chronic renal disease in Turkey - the CREDIT study / G. Suleymanlar, C. Utas, T. Arinsoy [et al.] // Nephrology Dialysis Transplantation. - 2011. - Vol. 26 (6). - P. 1862-1871.

36. Change in prevalence of chronic kidney disease in England over time: comparison of nationally representative crosssectional surveys from 2003 to 2010. / G. R. Aitken, P. J. Roderick, S. Fraser [et al.] // BMJ open. - 2014. - Vol. 4 (9).

37. Determinants and burden of chronic kidney disease in the population-based CoLaus study: a cross-sectional analysis / B. Ponte, M. Pruijm, P. Marques-Vidal [et al.] // Nephrology Dialysis Transplantation. - 2013. - Vol. 28 (9). -P. $2329-2339$. 38. Epidemiology of chronic kidney disease: results from a population of older adults in Germany / Q.-L. Zhang, W. Koenig, E. Raum [et al.] // Preventive Medicine. - 2009. - Vol. 48(2). - P. 122-127.

39. Health 2020 A European policy framework and strategy for the 21st century. - Copenhagen WHO EURO, 2011. - $190 \mathrm{p}$. 40. ISN Global Kidney Health Summit participants. Global kidney health 2017 and beyond: a roadmap for closing gaps in care, research, and policy / A. Levin, M. Tonelli, J. Bonventre [et al.] // Lancet. - 2017 - Vol. 390(10105). - P. $1888-1917$. 41. Luyckx Valerie A. The global burden of kidney disease and the sustainable development goals / Valerie A. Luyckx, Marcello Tonelli \& John W. Stanifer // Bulletin of the World Health Organization. - 2018. - Vol. 96. - P. 414-422D. doi: http:// dx.doi.org/10.2471/BLT.17.206441

42. Pearle M. Urological diseases in America project / M. Pearle, E. Calhoun, G. C. Curhan // J. Urol. - 2005. - Vol. 173. P. 848-857.

43. Prevalence and risk factors associated with chronic kidney disease in an adult population from southern China / W. Chen, W. Chen, H. Wang [et al.] // Nephrology Dialysis Transplantation. - 2009. - Vol. 24 (4). - P. $1205-1212$.

44. Prevalence and risk factors associated with chronic kidney disease in adults over 40 years: A population study from Central China / Y. Shan, Q. Zhang, Z. Liu [et al.] // Nephrology. - 2010. - Vol. 15 (3). - P. 354-361.

45. Prevalence and determinants of chronic kidney disease in community-dwelling elderly by various estimating equations / D. Rothenbacher, J. Klenk, M. Denkingeret [et al.] // BMC Public Health. - 2012. - Vol. 12. - P. 343.

46. Prevalence estimates of chronic kidney disease in Canada: results of a nationally representative survey / P. Arora, P. Vasa, D. Brenner [et al.] // CMAJ Canadian Medical Association Journal. - 2013. - Vol. 185 (9). - P. 417-423. 
47. Prevalence of chronic kidney disease and decreased kidney function in the adult US population: Third National Health and Nutrition Examination Survey / J. Coresh, B.C. Astor, T. Greene [et al.] // Am. J. Kidney Dis. - 2003. - Vol. 41. - P. 1-12. 48. Prevalence of chronic kidney disease and prediabetes and associated risk factors: a community-based screening in Zhuhai, Southern China / D.-F. Gu, Y.-L. Shi, Y.-M. Chen [et al.] // Chinese Medical Journal. - 2013. - Vol. 126 (7).

49. Risk factors for urinary tract infection in patients with urolithiasis-primary report of a single center cohort / Li Yongzhi, Yan Shi, Liu Jia [et al.] // BMC Urology. - 2018. - Vol. 18. - P. 45.

50. The prevalence of chronic kidney disease and its relation to socioeconomic conditions in an elderly Polish population: results from the national population-based study PolSenior / J. Chudek, K. Wieczorowska-Tobis, J. Zejda [et al.] // Nephrology Dialysis Transplantation. - 2014. - Vol. 29 (5). - P. 1073-1082.

\section{References}

1. Balka, L.O. (2015). Obhruntuvannia zahalnykh zasad medyko-psykholohichnoi dopomohy khvorym na sechokamianu khvorobu odniiei abo yedynoi nyrky [Justification of general principles of medical and psychological assistance to patients with urolithiasis of one or a single kidney]. Medychna psykholohiia - Medical Psychology, 2, 53-56 [in Ukrainian].

2. Vozianov, S.O., Saidakova, N.O., \& Startseva, L. M. (2015). Resursy ta osnovni pokaznyky diialnosti urolohichnoi sluzhby v Ukraini za 50 rokiv [Resources and main indicators of urological service activity in Ukraine for 50 years]. Urolohiia Urology, 2 (73), 9-19 [in Ukrainian].

3. Vozianov, S.O., Saidakova, N.O., \& Startseva, L.M. (2013). Stan i perspektyvy rozvytku urolohichnoi sluzhby v Ukraini [Status and prospects for the development of the Urology Service in Ukraine]. Urolohiia - Urology, 3, 89-95 [in Ukrainian]. 4. Gruzeva, T. (2014). Innovatsiina sutnist ta stratehichnyi i praktychnyi potentsial novoi Yevropeskoi polityky "Zdorovia-2020" [Innovative essence and strategic and practical potential of the new European policy "Health 2020"]. Visnyk problem biolohii ta medytsyny - Bulletin of Biological and Medical Problems, 3, 1(110), 25-33 [in Ukrainian].

5. Detsyk, O. Z. (2017). Suchasni pidkhody do orhanizatsii nadannia urhentnoi i planovoi medychnoi dopomohy pry sechokamianii khvorobi [Modern approaches to the organization of providing urgent and planned medical care for urolithiasis]. Zdorovye muzhchiny - Health of a Men, 2(61), 58-61 [in Ukrainian].

6. Dmytryshyn, S.P. (2012). Kliniko-orhanizatsiina model urolohichnoi dopomohy khvorym na sechokamianu khvorobu [Clinic-organizational model of urological help to patients with urolithiasis]. Candidate's Extended abstract. Kyiv [in Ukrainian].

7. Dulov, A.A., Borisov, V. ., \& Popova, G.V. (2014). Organizatsiya meditsinskoy pomoshchi bolnykh s zabolevaniyami mochepolovoy sistemy [Organization of medical care for patients with diseases of the urogenital system]. Sistemnyy analiz i upravleniye v biomeditsinskikh sistemakh - System Analysis and Management in Biomedical Systems, 13 (1), $150-156$ [in Russian].

8. Dulov, A.A., Borisov, V.A., \& Klepikov, O.V. (2013). Otsenka urovnya zabolevayemosti boleznyami mochepolovoy sistemy i ekzogennykh faktorov riska [Evaluation of the incidence of diseases of the urogenital system and exogenous risk factors]. Sistemnyy analiz i upravleniye $v$ biomeditsinskikh sistemakh. - System Analysis and Control in Biomedical Systems, 12 (1), 331-337 [in Russian].

9. Zhuravlev, V.N., Vakhlov, S.G., \& Makaryan, A.A. (2009). Klinicheskaya i trudovaya reabilitatsiya bolnykh pri krupnykh kamnyakh pochek posle DUVL v usloviyakh sanatoriya "Obukhovskiy" [Clinical and labor rehabilitation of patients with large kidney stones after ESWL in the conditions of the Obukhovsky sanatorium]. Uralskiy meditsinskiy zhurnal - Ural Medical Journal, 11 (65), 19-22 [in Russian].

10. Korenev, N.M., Tolmachyova, S.R., Bogmat, L.F., \& Kolomiets, A.M. (2009). Invalidnost detey s khronicheskimi somaticheskimi zabolevaniyami v Ukraine [Disability of children with chronic somatic diseases in Ukraine]. Zdorovye rebenka - Health of a Child, 3 (18), 25-31 [in Ukrainian].

11. Kogan, O.S., \& Badayev, F.I. (2010). Nekotoryye rezultaty reorganizatsii sistemy urologicheskoy pomoshchi muzhchinam $\checkmark$ Sverdlovskoy oblasti [Some results of the reorganization of the system of urological care for men in the Sverdlovsk region]. Vestnik Uralskoy meditsinskoy akademicheskoy nauki - Bulletin of the Ural Medical Academic Science, 4, 69-71 [in Russian].

12. Kogan, O.S. (2010). Sostoyaniye urologicheskogo zdorovya naseleniya v munitsipalnykh obrazovaniyakh Sverdlovskoy oblasti i faktory yego formiruyushchiye [The state of urological health of the population in the municipalities of the Sverdlovsk region and its formative factors]. Problemy upravleniya zdravookhraneniyem - Problems of Health Management, 6, 44-47 [in Russian].

13. Krylov, S.G. (2007). Analiz rezultatov sotsiologicheskogo issledovaniya patsiyentov urologicheskogo otdeleniya konsultativno-diagnosticheskogo tsentra [Analysis of the results of a sociological study of patients in the urological department of the consultative-diagnostic center]. Gumanitarnyye metody issledovaniya $v$ meditsine sostoyaniye $i$ perspektivy materialy nauchno-prakticheskoy konferentsii, Saratov: SMU, 308-310 [in Russian].

14. Krylov, S.G. (2006). Mediko-statisticheskaya kharakteristika bolnykh urologicheskogo otdeleniya oblastnoy bolnitsy [Medico-statistical characteristics of patients in the urological department of the regional hospital]. Problemy gorodskogo zdravookhraneniya - Problems of Urban Health, 11, St. Petersburg, 149-152 [in Russian].

15. Kuchma, I.L. (2013). Porivnialna otsinka yakosti zhyttia patsiientiv, yaki otrymuiut nyrkovu zamisnu terapiiu, pry vykorystanni standartnykh ta indyvidualnykh prohram likuvannia [Comparative assessment of the quality of life of patients receiving renal substitution therapy, using standard and individual treatment programs]. Medychna informatyka ta inzheneriia - Medical Informatics and Engineering, 3, 24-27 [in Ukrainian].

16. Makaryan, A.A. (2012). Kachestvo zhizni bolnykh mochekamennoy boleznyu posle provedennogo lecheniya [Quality of life in patients with urolithiasis after treatment]. Materials of the 67th All-Russian Scientific and Practical Conference of Young Scientists and Students with International Participation, Ekaterinburg, 603-606 [in Russian]. 
17. Makaryan, A.A., Zhuravlev, V.N., \& Borzunov, I.V. (2012). Organizatsiya klinicheskoy reabilitatsii bolnykh mochekamennoy boleznyu posle provedennogo operativnogo lecheniya $v$ sanatorii "Obukhovskiy" [Organization of clinical rehabilitation of patients with urolithiasis after surgical treatment in the sanatorium "Obukhovsky"]. Farmatsiya i obshchestvennoye zdorovye. Materialy yezhegodnoy konferentsii. Ekaterinburg, 370-372 [in Russian].

18. Mashin, A.G. (2011). Zabolevayemost i invalidnost v svyazi s boleznyami mochepolovoy sistemy [Morbidity and disability due to diseases of the genitourinary system]. Aktualnyye aspekty vnedreniya innovatsionnykh tekhnologiy $v$ praktiku osushchestvleniya mediko-sotsialnoy ekspertizy s ispolzovaniyem polozheniy MKF, Rostov-na-Donu, 285-286 [in Russian].

19. Mashin, A.G. (2011). Resursosberegayushchiye tekhnologii v urologii [Resource-saving technologies in urology]. Teoriya i praktika dostizheniy sovremennoy meditsiny. Materialy mezhinstitutskoy nauchnoy konferentsii s mezhdunarodnym uchastiyem, posvyashchennoy 100-letiyu so dnya rozhdeniya G.N. Beletskogo, Moscow, 47-48 [in Russian].

20. Mesto zdravookhraneniya $\vee$ Povestke dnya $\vee$ oblasti razvitiya na period posle $2015 \mathrm{~g}$. [Place of health care in the post-2015 development agenda]. Retrieved from: http://www.who.int/topics/millennium_development_goals/post2015/ WHOdiscussionpaper_October2012_ru.pd [in Russian].

21. Mosiienko, H.P. (2013). Poshyrenist sechokamianoi khvoroby sered viskovosluzhbovtsiv za danymy ultrazvukovoi diahnostyky [Prevalence of urolithiasis among military personnel according to ultrasound diagnostics]. Zdorovye muzhchiny - Health of a Men, 2 (45), 117-119 [in Ukrainian].

22. (2014). Osushchestvleniye kontseptualnogo videniya politiki Zdorovye-2020: strategicheskoye rukovodstvo v interesakh zdorovya $v$ XXI veke [Implementing the conceptual vision of the Health 2020 policy: strategic leadership for the health of the 21st century]. Copenhagen, WHO / Europe [in Russian].

23. Pasechnikov, S.P., Saidakova, N.O., \& Dmitrishin S.P. (2009). Dynamika efektyvnosti ta rivnia orhanizatsiii spetsializovanoi dopomohy patsiientam iz sechokamianoiu khvoroboiu $v$ Ukraini [Dynamics of the effectiveness and level of organization of specialized care for patients with urolithiasis in Ukraine]. Zdorovye muzhchiny - Health of a Men, 1, 164171 [in Ukrainian].

24. Vozianov, S.O., Saidakov, N.O., Hryhorenko, V.M., Onyshchuk, A.P., \& Oniskov O.O. (2015). Pervynna, zahalna zakhvoriuvanist, smertnist vid osnovnykh khvorob orhaniv sechostatevoi systemy v aspekti diialnosti DU "Instytut urolohii NAMN Ukrainy" [Primary, general morbidity, mortality from major diseases of the organs of the genitourinary system in the aspect of the activity of the State Institution "Institute of Urology of NAMS of Ukraine"]. Urolohiia - Urology, 19, 3 (74), 15-28 [in Ukrainian].

25. Pribitkov, G.N. (2007). Sovremennyye tendentsii v zabolevayemosti organov mochepolovoy sistemy u naseleniya yuga Tyumenskoy oblasti [Current trends in the incidence of organs of the genitourinary system in the population of the south of the Tyumen region]. Meditsinskaya nauka i obrazovaniye Urala - Medical science and education of the Urals, 3, 57-59 [in Russian].

26. Pribytkov, G.N., Maksimovskikh, V.I., \& Mariupolskiy, A.A. (2001). Urofloumetricheskiy kontrol pri lechenii khronicheskogo prostatita [Uroflow measurement in the treatment of chronic prostatitis]. Nauchnyy vestnik Tyumenskoy meditsinskoy akademii - Scientific Bulletin of the Tyumen Medical Academy, 2, 23 [in Russian].

27. Stakhovsky, E.O., Saydakov, N.O., Vitruk, Yu.V., \& Dmitrishin, S.P. (2017). Prychyny invalidnosti naselennia Ukrainy vnaslidok zakhvoriuvan sechostatevoi systemy ta shliakhy yikh zmenshennia [Causes of invalidity of the population of Ukraine as a result of diseases of the urogenital system and ways of their reduction]. Urolohiia - Urology, 21, 1(80), 45-52 [in Ukrainian].

28. Rezoliutsiya "Strategiya v podderzhku zdorovya i blagopoluchiya muzhchin v Yevropeyskom regione VOZ" [Resolution "Strategy to support men's health and well-being in the WHO European Region"]. Retrieved from: http://www.euro.who. int/_data/assets/pdf_file/0003/382251/68rs04r_MensHealthStrategy_180668.pdf?ua=1

29. Ruda, V.I. (2015). Riven invalidnosti pry zakh̄oriuvanniakh orhaniv sechovydilnoi systemy u ditei Khmelnytskoi oblasti [The level of disability in diseases of urinary tract organs in children of Khmelnitsky region]. Aktualnye voprosy pediatrii Actual Questions of Pediatrics, 4 (68), 53-56 [in Ukrainian].

30. Sobchynskyi, K.S. (2016). Kompleksne likuvannia ureterolitiazu v ambulatornykh umovakh ta profilaktyka yoho uskladnen [Complex treatment of ureterolithiasis in ambulatory conditions and prevention of its complications]. Candidate's extended abstract. Kyiv [in Ukrainian].

31. Solomchak, D.B. (2015). Analiz orhanizatsii dyspansernoho sposterezhennia khvorykh na sechokamianu khvorobu [Analysis of the organization of dispensary observation of patients with urolithiasis]. Halytskyi likarskyi visnyk - Galician Medicinal Herald, 22 (1), 127-130 [in Ukrainian].

32. Solomchak, D.B. (2015). Analiz orhanizatsii sanatorno-kurortnoho likuvannia khvorykh na sechokamianu khvorobu [Analysis of the organization of sanatorium and resort treatment for patients with urolithiasis]. Medychna hidrolohiia ta reabilitatsiia - Medical Hydrology and Rehabilitation, 12 (1-4), 7-14 [in Ukrainian].

33. Kniazevych, V.M., Bilynska, M.M., \& Zhalilo, L.I. (2015). Suchasni napriamy rozvytku system okhorony zdorovia krain Yevropy: naukovo-metodychni rekomendatsii [Modern trends in the development of health systems in Europe: scientific and methodological recommendations]. Kniazevych, V.M. (Ed.). Kyiv [in Ukrainian].

34. Shchorichna dopovid pro stan zdorovia naselennia, sanitarno-epidemichnu sytuatsiiu ta rezultaty diialnosti systemy okhorony zdorova Ukrainy. 2016 rik [Annual report on the health status of the population, the sanitary and epidemiological situation and the results of the health care system of Ukraine. 2016]. (2017). MOZ Ukrainy, DU «UISD MOZ Ukrainy» Ministry of Health of Ukraine, UISD MOH Ukraine, Kyiv [in Ukrainian].

35. Suleymanlar, G., Utas, C., Arinsoy, T., Ates, K., Altun, B., Altiparmak, M.R. \& et al. (2011). A population-based survey of Chronic REnal Disease In Turkey - the CREDIT study. Nephrology Dialysis Transplantation, 26 (6), 1862-1871. 
36. Aitken, G.R., Roderick, P.J., Fraser, S., Mindell, J.S., O’Donoghue, D., Day, J., et al. (2014). Change in prevalence of chronic kidney disease in England over time: comparison of nationally representative cross-sectional surveys from 2003 to 2010. BMJ Open., 4 (9).

37. Ponte, B., Pruijm, M., Marques-Vidal, P., Martin, P.-Y., Burnier, M., Paccaud, F., \& et al. (2013). Determinants and burden of chronic kidney disease in the population-based CoLaus study: a cross-sectional analysis. Nephrology Dialysis Transplantation, 28 (9), 2329-2339.

38. Zhang, Q.-L., Koenig, W., Raum, E., Stegmaier, C., Brenner, H., \& Rothenbacher, D. (2009). Epidemiology of chronic kidney disease: results from a population of older adults in Germany. Preventive Medicine, 48 (2), 122-127.

39. (2011). Health 2020 A European policy framework and strategy for the 21st century. Copenhagen WHO EURO.

40. Levin, A., Tonelli, M., Bonventre, J., Coresh, J., Donner, J.A., Fogo, A.B., et al. (2017). ISN Global Kidney Health Summit participants. Global kidney health 2017 and beyond: a roadmap for closing gaps in care, research, and policy. Lancet, 390 (10105), 1888-1917.

41. Valerie A. Luyckx, Marcello Tonelli \& John W. Stanifer (2018). The global burden of kidney disease and the sustainable development goals. Bulletin of the World Health Organization, 96, 414-422 doi: http://dx.doi.org/10.2471/BLT.17.206441 42. Pearle, M., Calhoun, E., \& Curhan, G.C. (2005). Urological diseases in America project. J. Urol., 173, 848-857.

43. Chen, W., Chen, W., Wang, H., Dong, X., Liu, Q., Mao, H., et al. (2009). Prevalence and risk factors associated with chronic kidney disease in an adult population from southern China. Nephrology Dialysis Transplantation, 24 (4), 1205-1212. 44. Shan, Y., Zhang, Q., Liu, Z., Hu, X., \& Liu, D. (2010). Prevalence and risk factors associated with chronic kidney disease in adults over 40 years: A population study from Central China. Nephrology, 15 (3), 354-361.

45. Rothenbacher, D., Klenk, J., Denkinger, M., Karakas, M., Nikolaus, T., Peter, R., \& et al. (2012). Prevalence and determinants of chronic kidney disease in community-dwelling elderly by various estimating equations. BMC Public Health, 12, 343.

46. Arora, P., Vasa, P., Brenner, D., Iglar, K., McFarlane, P., Morrison, H., \& et al. (2013). Prevalence estimates of chronic kidney disease in Canada: results of a nationally representative survey. CMAJ Canadian Medical Association Journal, 185(9), 417-423.

47. Coresh, J., Astor, B.C., Greene, T. \& et al. (2003). Prevalence of chronic kidney disease and decreased kidney function in the adult US population: Third National Health and Nutrition Examination Survey. Am. J. Kidney Dis., 41, 1-12.

48. Gu, D.-F., Shi, Y.-L., Chen, Y.-M., Liu, H.-M., Ding, Y.-N., Liu, X.-Y., et al. (2013). Prevalence of chronic kidney disease and prediabetes and associated risk factors: a community-based screening in Zhuhai, Southern China. Chinese Medical Journal, 126 (7).

49. Li Yongzhi, Yan Shi, Liu Jia, Liu Yili, Zhu Xingwang \& Gong Xue (2018). Risk factors for urinary tract infection in patients with urolithiasis - primary report of a single center cohort. BMC Urology, 18, 45.

50. Chudek, J., Wieczorowska-Tobis, K., Zejda, J., Broczek, K., Skalska, A., Zdrojewski, T. et al. (2014). The prevalence of chronic kidney disease and its relation to socioeconomic conditions in an elderly Polish population: results from the national population-based study PolSenior. Nephrology Dialysis Transplantation, 29 (5), 1073-1082.

\section{РАСПРОСТРАНЕННОСТЬ УРОЛОГИЧЕСКОЙ ПАТОЛОГИИ И ПРОБЛЕМЫ ОРГАНИЗАЦИИ ПРЕДОСТАВЛЕНИЯ УРОЛОГИЧЕСКОЙ ПОМОЩИ НАСЕЛЕНИЮ (ОБЗОР НАУЧНОЙ ЛИТЕРАТУРЫ)} М. Д. Дячук

Государственное научное учреждение «Научно-практический центр профрилактической и клинической медицины» ГУД, г. Киев, Украина

Цель: выявление современного состояния разработки проблемы организации медицинской помощи пациентам урологического профиля и перспективы дальнейших исследований.

Материалы и методы. При выполнении исследования использованы библиографический метод и метод контент-анализа.

Результаты. Несмотря на тяжесть медико-социальных проблем, связанных с болезнями мочеполовой системы, исследования по данной тематике крайне немногочисленны. Они посвящены изучению масштабов распространения патологии, ведущих фракторов влияния, совершенствованию технологий лечения, решению вопросов борьбы с отдельными болезнями мочеполовой системы, прежде всего с мочекаменной болезнью, инфекциями и хроническими болезнями почек, и организации медицинской помощи отдельным категориям населения, преимущественно в региональном контексте.

Остаются нерешенными вопросы медико-организационного характера. Это требует комплексного подхода с учетом широкого спектра патологии, многих фракторов влияния, современных стратегий развития урологической службы, интегративных тенденций, профилактических концепций, пациенториентованого подхода и тому подобное.

Выводы. Анализ научной литературы показал недостаточную разработку проблемы сокращения урологической патологии, ее негативных последствий, необходимость научного обоснования совершенствования системы предоставления урологической помощи населению в условиях реформирования здравоохранения.

КЛЮЧЕВЫЕ СЛОВА: болезни мочеполовой системы; заболеваемость; распространенность; организация урологической помощи; факторы; качество; функционально-структурная модель. 


\section{PREVALENCE OF UROLOGICAL PATHOLOGY AND PROBLEMS OF THE ORGANIZATION OF UROLOGICAL CARE FOR THE POPULATION (SCIENTIFIC LITERATURE REVIEW)}

Diachuk M.D.

State Scientific Institution "Scientific-Practical Center for Preventive and Clinical Medicine", Kyiv, Ukraine

Purpose: identification of the current state of development of the problem of organization of medical care for patients of urological profile and prospects for further research.

Materials and Methods. In the course of the research the bibliographical method and the method of content analysis were used.

Results. Despite the burden of medical and social problems associated with diseases of the urogenital system, the study of the subject matter is extremely small. They are devoted to the study of the extent of the spread of pathology, the leading factors of influence, the solution of issues of combating certain diseases of the urogenital system, primarily with urolithiasis, infections and chronic kidney diseases, and the organization of medical care for certain categories of the population, mainly in the regional context.

There remains a number of unresolved issues of medical and organizational nature, which requires a complex approach taking into account a wide range of pathology, many factors of influence, modern strategies for the development of urological service, integrative trends, preventive concepts, patient-oriented approach etc.

Conclusions. The analysis of scientific literature revealed insufficient development of the problem of reduction of urological pathology, its negative consequences, has shown the necessity of scientific substantiation of improvement of the system of providing urological care for the population in the conditions of health care reform.

KEY WORDS: diseases of the urogenital system; morbidity; prevalence; organization of urological care, factors; quality; functional and structural model.

Рукопис надійшов до редакції 19.09.2018 p.

\section{Відомості про автора:}

Дячук Михайло Дмитрович - кандидат медичних наук, науковий співробітник наукового відділу малоінвазивної хірургії ДНУ «НПЦ ПКМ» ДУС (Державна наукова установа «Науково-практичний центр профрілактичної та клінічної медицини» Державного управління справами); тел.: +38(095) 777-77-69. 